\title{
Pedagogic Tenets of Specification Writing in Architectural Education, Construction and Practice
}

\author{
Bukola Adewale $^{\mathrm{a}}$,Peter Aderonmu ${ }^{\mathrm{a}}$, Paul Awoyera ${ }^{\mathrm{b}}$, Omoyeni Fulania ${ }^{\mathrm{a}}$, Foluke Jegede ${ }^{\mathrm{a}}$, Emokpae Erebor $^{\mathrm{a}}$ \\ ${ }^{a}$ Department of Architecture, Covenant University, Ota, Nigeria \\ ${ }^{b}$ Department of Civil Engineering, Covenant University, Ota, Nigeria \\ *Corresponding author: paul.awoyera@covenantuniversity.edu.ng
}

\begin{abstract}
Specification writing is an important aspect of architectural curriculum; as failure of the architect to write an effective specification in educational training and construction-practice may lead to unpalatable factors. This study explored couple of methods employed in the teaching, learning and assessment of specification writing students in architecture department, Covenant University, South-West Nigeria, with a view to identifying the most effective method within the group dynamics. The methodology adopted for this study involved the interview of M.Sc. II architecture students and adoption of two (2) basic pedagogic methods namely Traditional and Revolutionary during class sessions. The qualities were evaluated and assessed through the outcome of students' assignments, standard performance tests and examinations results, and documentations in brainstorming-interactive class sessions. It was found that there were significant differences between the performance scores of students using diverse pedagogic methods. It recommended that further research capable of bridging education and construction- practice in synergy.
\end{abstract}

Keywords: Architecture; construction; education; practice; specification

(c) 2016 Penerbit UTM Press. All rights reserved

\subsection{INTRODUCTION}

Literarily, specification is a detailed description of how something is, or should be, designed or made (OALD8, 2010). It can also be defined as a fashion after which something should be made (KJV, 2013); a key component in the education training of an architect and other allied professionals. This phenomenon is imperative during the building material procurement, bidding, tendering, maintenance, budgeting, and costing process; one of the sensitive determinant factors of the quality of construction (Ali, 2009; Ali, Kamaruzzaman, Sulaiman, and Peng, 2010; Yiu, 2008) as it helps all the decision makers to work effectively.

In Nigeria, specification is enfaced with challenges like the use of unfamiliar standards, lack of consistency amongst documents, difficulty in searching for information and language problems among other shortfalls (Lam, Kumaraswamy, and Ng, 2001) which makes it difficult for its operation, first, in the nature of pedagogic tenets offered schools and second, in professional practice of architecture in Nigeria (McFarland, 2010). In schools, since the root of traditional model of teaching is hardly divorced from the revolutionary or contemporary, accountability is required of Teacher Preparation Programmes (TPPs) in the pedagogic dynamics and ethical demands in professional practice (PP). This demands titivated this study (Lincove, Osborne, Dillon, and Mills, 2014) and it is aimed to explore the prospects of hybridization domicile in the traditional-didactic (chalk and talk) and the revolutionary-problem-based learning (PBL) methods to maximize benefits that can be dovetailed into the construction practice after graduation.

\subsection{LITERATURE REVIEW}

\subsection{Architectural Education in Nigeria}

From the inception of Architectural design studio in the nineteenth century, tremendous changes have not been substantial from the historical models of the Ecole des Beaux-Arts and the Bauhaus Schools (Olotuah, 2002, Aderonmu, 2013). The Beaux-Arts school originated in the nineteenth century when the two modes of teaching (Mimesis and Analysis), received emphasis in architectural education. Mimesis or imitation, was originally exemplified by the medieval "bottegha". In the bottegha, the student was a worker for a "master", acquiring both technique and philosophy. The student intimately learned to reproduce the gesture which essentially was locked into his master's style. Mimesis was later engaged in the Ecoles des Beaux Arts educational system in which students received instruction in the "Studio" of the professors practically learning from the feet of the master the ways architectural offices operate (Aderonmu, 2013).

Conversely, the analytic method attempted to teach issues and principles of architecture by examining its history, and by teaching specific methods of analysis in order to develop systems of coherent criticisms, unbiased contributions to students' work in the Jury assessment techniques and presentation styles from a unique position (Bucholtz and Monk, 1984). 
The "Staatliche Bauhaus Weimar" was founded in 1919 by Walter Gropius with the aim of uniting arts, crafts and architecture training within a single institution and reforming living and housing conditions. It explored new approaches to printing, metalwork, weaving, pottery, and stage craft, as well as architecture.

Noticeably, the last three decades have witnessed a substantial shift in architectural design education with changes driven mainly by epistemological, social, and economical forces among which are new knowledge and technological developments, increased use of computers and information technology in design education and practice, pressure on institutions of higher education to reduce space use, and changing student demographics. In another development of seeking effective cross-cultural design pedagogy in Australia, UNESCO'S Regional director, Dr Viktor Ordonez made the following comments:

"The drive towards internationalizing must not be at the sacrifice of undervaluing the importance of traditional cultures, local identity and community. We have to preserve the balance between universalism, modernization and a sense of local identity. They should not have to compete. One cannot sacrifice a sense of local identity for a sense of global identity" (UIA/UNESCO,1996).

More so, pedagogy (Teaching, learning and assessment) cannot exist in a vacuum, but operates in a specific environment (physical, estudio, paperless, virtual etc.); therefore, different internal and external conditions are necessary for each type of learning (Kearsley, 19942008). In the context of architectural design studio, consequently, it is needful that students need to be asked questions about their perceptions of learning, the collective learning of the class, and about the instructional practices of the teacher, all within the cultural setting of the studio.

Another scholar (Aderonmu, 2013) inclusively asserted that "contemporary matters of teaching, learning and assessment methods cannot be divorced from its past, chronology and history. Therefore, glimpses of the historical past may yet deliver strong revelations of some useful traditional elements capable of engendering today's revolutionary pedagogy. If synergy of traditional-didatic is pragmatically engaged with the dynamics of the contemporary-revolutionary styles, the outcome could also supply sustainable indices; which may be found useful for the capacity building, development, proficiency and competency of skills required of future professionals for civic engagements.

\subsection{Learning styles}

Generally, Learning styles refer to the variations in the ability to accumulate as well as assimilate information; it is the method that best allows one to gather and use knowledge in a specific manner. Among myriads of categorization of learning styles, i.e kolb, Grasham, e.t.c., experts agree that there are three basic learning styles: visual, auditory and kinesthetic learner.

Visual learners learn through what they can see with their own eyes. They strive to sit at the front of the class, front row of theater seats and up in front of the stadium and pavilion seats for sporting events in order to obtain the best view. Other attributes are tendency to describe everything that they see in terms of appearances, love visual aids such as photos, diagrams, maps and graphs, frequently good writers and commonly perform quite well on written assignments.

Auditory learners are very good listeners. They tend to absorb information in a more efficient manner through sounds, music, discussions, teachings, etc. These individuals will be more likely to record lectures so that they can replay them at a later time for study purposes. Auditory learners appreciate books on tape and may find that reading aloud will help them to retain information. Rather than written reports, auditory learners tend to do better on oral presentations and reports (Learning Directory, 2010).

The kinesthetic learners are tactile in nature. It means that they get information and best assimilate through moving, doing, acting out and touching activities. The teachers can therefore orient the predilections towards projects that are hands-on in nature which are best for kinesthetic learners. This category of learners tends to become frustrated when they are compelled to sit for long periods of time. There are enthused and have strong predilections for activities that involve conducting experiments, exploration and performance tasks.

In a class situation, each individual may possess a single style or better still could possess a combination of different learning styles. In most cases, the characteristics of a learning style can even be observed at a relatively young age, especially during participatory engaged activities-hands on experiences. But specifically, for the purpose of this investigation, the learning methods explored were the traditionaldidactic and revolutionary PBL methods.

\subsection{Philosophic Mindsets of the Traditional and Revolutionary Methods of Teaching}

Aderonmu (2012) concluded that capacity development of future professionals be equipped with relevant Vocational Technical Education (VTE) Dieted courses in the flexible manner that would allow to meet the needs of clients, communities and societies. Also student architects, engineers and others in allied professions should be pedagogically integrated for a project task, so that while in school, it would develop art of synergy and foster productivity in team work after graduation. But a wide gap needed to be filled in terms of skill acquisition, proficiency and competence needed to match up with contemporary challenges of development (Olukanni, Aderonmu, Ogbiye, and Akinwunmi, 2014).

Although, the traditional pedagogy has been vehemently criticized at the advent of the revolutionary styles ; but in the philosophical dimension of John Dewey (Dewey, 1904;1938) who asserted five core beliefs of traditional mindsets of educational training that education has been conducted with the following objectives (a) to be disconnected from the experiences that the students brought from their homes and their community, (b) to be disconnected from the practical and manual activity through which they are engaged with experience, (c) to ignore the interest that motivated young people to learn, (d) to treat knowledge as something purely symbolic and formal-organized in texts, 'stuck on' without connections to experience or existing ways of understanding, (e) to maintain discipline through external authority rather than through the engagement of the young people (Pring, 2007).

The revolutionary measures of pedagogy, as opposed to the traditional mindset, stated that instead of disconnecting students from the built-up home and community experiences, school should therefore be seen as the extension of the home and the community. In this way, students would expend much from practical knowledge picked up informally in family and community. The school should aim in this wise 
through the 'modus operandi' of the curriculum to deepen and entrenching such understanding in context relevance of traditional knowledge in terms of the school's philosophy, policy, curriculum and syllabus. This will enable the young people to reflect upon the traditional knowledge context and incorporating its value into their professional services and civic engagements after graduation. For professionally trained architects who are oriented in this schema, they would be able to return to the community with something sustainable and can meet the true needs of the benefitted homes and communities (Adewale et al., 2014) - the educational aim.

\subsection{RESEARCH METHODOLOGY}

The methodology in this study evaluated different tenets of instructions, approaches, and principles used in specification writing in architecture department, Covenant University, Nigeria. It assesses teaching through various parameters like students' performance in tests, examinations, interactive class sessions, debate, and group focus. It evaluates the effect of various learning methodologies on the performance of architecture students in specification writing at Covenant University. The relationship between learning/teaching methodologies and performance score of students was examined. Post graduate Students of 2014/2015 academic session were chosen as the sample frame. They were taken through a series of teaching styles. Two different methods were identified namely: Traditional and Revolutionary. At the end of each style, assessment was conducted to evaluate students' preferences for learning styles.

\subsection{Class Work}

\subsubsection{Module 1: Week 1-3}

The first module consisted of three lectures taken for three weeks. In the first week of lecture, group dynamics method of learning was employed. The content of the lecture was to establish the importance and uses of specification and to identify the reasons for its neglect if it was so important. They were free to source information from the internet, through intra group debates and textbooks. Eventually, they were asked to prepare reports on reasons for neglect of specification and submit after four days.

The second week of the first module covered the various approaches to specification writing and limitations of specification. The first stage of the lecture period, which lasted for forty minutes, was used for the explanation of the different approaches to specification writing. After entertaining questions for ten minutes, the second step, which lasted for sixty minutes, was used for debating on the preferred approach for writing specification in the views of the different groups. In this step, the representatives of the groups were asked to explain the advantages of their preferred approach over others. Each of the groups was later assessed.

The third week of lecture exposed students to the principles of specification writing and selection of materials. Samples of specification were distributed to the various groups to check for adherence to the principles. Students' knowledge of building materials was tested with a simple toilet finish specification.

The fourth week of lecture exposed students to specification formats. The lecturer was the main participant here. After this module, it was assumed that the students had learnt the basic principles that would guide them in writing good specification. They were tested after this module on the things learned so far.

\subsubsection{Module 2:}

In the first and second weeks after the completion of module one, the Teacher focused on the Construction Specification Institute (CSI) format of specification. She sets standards and defined acceptable format of (doing things) writing the CSI format. The formats were taken to class and students were made to write two divisions namely "finishes" and "openings". A test was later conducted to test their understanding of the CSI format (dependent style).

The third and fourth week of module 2 focused on National Building Specification (NBS) format. A class work was given where students were asked to write specification of Ceramics and Concrete work sections (independent style)

\subsubsection{Module 3:}

Sample specification of the full version of the CSI and NBS formats were given to students to enable them write specification for their design project for the semester. They were asked to choose four clauses that were relevant to their design project.

\subsection{Assessment Scale}

\subsubsection{Module 1:}

Assessment for Module 1 was on weekly basis. For the group report on the reason for neglecting specification in architectural practice and the effect of neglect, students were expected to define specification, its importance in practice, its neglect and reasons; and the effect of neglect (Table 1). The assessment was done on a five point Likert scale of 5 (Excellent) to 1 (fail). 
Table 1 Assessment criteria and scoring rubrics for week 1

\begin{tabular}{|c|c|c|c|c|c|}
\hline $\begin{array}{l}\text { Neglect of Specification in } \\
\text { Architectural Education- } \\
\text { practice }\end{array}$ & Excellent (A) & Very Good $(B)$ & Fair $(\mathbf{C})$ & Poor (D) & Fail $(\mathbf{F})$ \\
\hline 1.Definition of specification & $\begin{array}{l}\text { Ability to render a concise \& } \\
\text { meaningful definition of } \\
\text { specification, what it is and } \\
\text { what it is not. }\end{array}$ & $\begin{array}{l}\text { A concise definition of } \\
\text { specification and what it } \\
\text { is }\end{array}$ & $\begin{array}{l}\text { A concise definition } \\
\text { of specification }\end{array}$ & $\begin{array}{l}\text { Vague definition } \\
\text { of specification }\end{array}$ & $\begin{array}{l}\text { Off-Point } \\
\text { definition }\end{array}$ \\
\hline $\begin{array}{l}\text { 2.The importance and uses of } \\
\text { specification in practice }\end{array}$ & $\begin{array}{l}\text { Expected to mention at least } 9 \\
\text { uses at different } \\
\text { stages(3stages)of construction }\end{array}$ & $\begin{array}{l}\text { Ability to mention } 7 \\
\text { uses at the } 3 \text { stages of } \\
\text { construction }\end{array}$ & $\begin{array}{l}\text { Ability to mention } 5 \\
\text { uses at the } 3 \text { stages }\end{array}$ & $\begin{array}{l}\text { Ability to } \\
\text { mention } 3 \text { uses } \\
\text { at the } 3 \text { stages }\end{array}$ & 1 use only \\
\hline 3.Neglect and its reasons & $\begin{array}{l}\text { a. Substantiating with } \\
\text { reference to existing literature } \\
\text { that there was neglect } \\
\text { b.Stating five (5) reasons for } \\
\text { neglect }\end{array}$ & $\begin{array}{l}\text { a. Substantiating with } \\
\text { reference to existing } \\
\text { literature that there was } \\
\text { neglect } \\
\text { b. Stating five (4) } \\
\text { reasons for neglect }\end{array}$ & $\begin{array}{lr}\text { Stating } 3 & \text { reasons } \\
\text { responsible } & \text { for } \\
\text { neglect(no reference) }\end{array}$ & $\begin{array}{l}\text { Stating } 2 \text { reasons } \\
\text { responsible for } \\
\text { neglect(no } \\
\text { reference) }\end{array}$ & $\begin{array}{l}\text { Stating } \\
\text { reason } \\
\text { responsible for } \\
\text { neglect(no } \\
\text { reference) }\end{array}$ \\
\hline 4.Effect of neglect on practice & $\begin{array}{l}\text { Evidence-based statements } \\
\text { and explanation of at least } \\
\text { five effects of neglect on } \\
\text { practice with references }\end{array}$ & $\begin{array}{l}\text { Stating and explaining } \\
\text { at least four effects of } \\
\text { neglect on practice with } \\
\text { references }\end{array}$ & $\begin{array}{l}\text { Stating } r \text { and } \\
\text { explaining at least } \\
\text { three effects of } \\
\text { neglect on practice } \\
\text { with references }\end{array}$ & $\begin{array}{l}\text { Stating and } \\
\text { explaining at } \\
\text { least two effects } \\
\text { of neglect on } \\
\text { practice with } \\
\text { references }\end{array}$ & $\begin{array}{l}\text { Stating and } \\
\text { explaining at } \\
\text { least one effect } \\
\text { of neglect on } \\
\text { practice with } \\
\text { references }\end{array}$ \\
\hline
\end{tabular}

For the week 2, the scheme was centered on debating over the approaches of specification; the 'scoring rubric' was as presented in Table 2. In the debate, it was expected that the students should display a very good understanding of the different types of approaches of writing construction specification. Also, students' creativity and critical thinking on why his preferred approach was the best were tested. The scoring rubric used had five scales ranging from Excellent (5) to fail (1). The sum of the three items scored formed the overall grade.

Table 2 Assessment criteria and scoring rubrics for week 2

\begin{tabular}{|c|c|c|c|c|c|}
\hline $\begin{array}{ll}\text { APPROACHES } & \text { OF } \\
\text { SPECIFICATION } & \\
\end{array}$ & Excellent (A) & Very Good (B) & Fair (C) & Poor (D) & Fail (F) \\
\hline 1.Understanding of approaches & $\begin{array}{l}\text { Being able to explain four } \\
\text { approaches }\end{array}$ & $\begin{array}{lr}\begin{array}{l}\text { Being able to } \\
\text { explain } \\
\text { approaches }\end{array} & \text { three } \\
\end{array}$ & $\begin{array}{lr}\begin{array}{l}\text { Being able } \\
\text { explain } \\
\text { approaches }\end{array} & \text { two } \\
\end{array}$ & $\begin{array}{lr}\begin{array}{l}\text { Being able } \\
\text { explain } \\
\text { approaches }\end{array} & \text { one } \\
\end{array}$ & $\begin{array}{l}\text { Not able to explain } \\
\text { any of the } \\
\text { approaches }\end{array}$ \\
\hline 2. Creativity & $\begin{array}{l}\text { Stating four (4) good } \\
\text { reasons for choosing a } \\
\text { particular approach }\end{array}$ & $\begin{array}{l}\text { Stating three }(3) \\
\text { good reasons for } \\
\text { choosing a particular } \\
\text { approach }\end{array}$ & $\begin{array}{l}\text { Stating two (2) good } \\
\text { reasons for choosing } \\
\text { a particular } \\
\text { approach }\end{array}$ & $\begin{array}{lr}\text { Stating one } & (1) \\
\text { good reason for } \\
\text { choosing } a \\
\text { particular approach }\end{array}$ & $\begin{array}{l}\text { Not able to give } \\
\text { any reason }\end{array}$ \\
\hline 3. Critical Thinking & $\begin{array}{l}\text { Ability to present the } \\
\text { reasons why an approach } \\
\text { is better than others by } \\
\text { comparison stating four } \\
\text { points }\end{array}$ & $\begin{array}{l}\text { Ability to present } \\
\text { the reasons why an } \\
\text { approach is better } \\
\text { than others by } \\
\text { comparison stating } \\
\text { three points }\end{array}$ & $\begin{array}{l}\text { Ability to present } \\
\text { the reasons why an } \\
\text { approach is better } \\
\text { than others by } \\
\text { comparison stating } \\
\text { two points }\end{array}$ & $\begin{array}{l}\text { Ability to present } \\
\text { the reasons why an } \\
\text { approach is better } \\
\text { than others by } \\
\text { comparison stating } \\
\text { one points }\end{array}$ & $\begin{array}{l}\text { Inability to present } \\
\text { any reason }\end{array}$ \\
\hline 4. Good presentation & $\begin{array}{l}\text { Ability of the student to } \\
\text { convince the audience that } \\
\text { his preferred approach is } \\
\text { truly the best. }\end{array}$ & $\begin{array}{l}\text { Ability of the } \\
\text { student to convince } \\
\text { the audience that his } \\
\text { preferred approach } \\
\text { is truly the best. }\end{array}$ & $\begin{array}{l}\text { Ability of the } \\
\text { student to convince } \\
\text { the audience that his } \\
\text { preferred approach } \\
\text { is truly the best. }\end{array}$ & $\begin{array}{l}\text { Ability of the } \\
\text { student to convince } \\
\text { the audience that } \\
\text { his preferred } \\
\text { approach is truly } \\
\text { the best. }\end{array}$ & 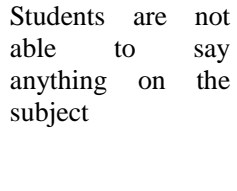 \\
\hline
\end{tabular}

For the week 3 lecture, eight (8) principles of specification writing were identified in literature. The lecturer brought samples of specifications that were non-adherent to some of the principles of specification. The students were expected to identify the faulty parts in the given specifications and there after suggest better ways of presentation. Again, assessment was on a five point Likert scale ranging from 5 (excellent) to 1 (very poor). Table 3 shows the summary of the assessment. 
Table 3 Assessment criteria and scoring rubrics for week 1 scoring rubric for week 3

\begin{tabular}{|l|l|l|l|l|l|}
\hline $\begin{array}{l}\text { Principles of specification } \\
\text { writing }\end{array}$ & Excellent (A) & Very Good (B) & Fair (C) & Poor (D) \\
\hline 1.Identification of faults & $\begin{array}{l}\text { Identification of all faults } \\
\text { in the given specification }\end{array}$ & $\begin{array}{l}\text { At least, 60\% of } \\
\text { faults should be } \\
\text { identified }\end{array}$ & $\begin{array}{l}\text { Being able to detect } \\
\text { at least 50\% of the } \\
\text { faults }\end{array}$ & $\begin{array}{l}\text { Being able to detect } \\
\text { at least 45\% of the } \\
\text { faults }\end{array}$ & $\begin{array}{l}\text { Being able to } \\
\text { detect } \\
45 \% \text { of the faults }\end{array}$ \\
\hline 2.Corrections & $\begin{array}{l}\text { Ability to suggest correct } \\
\text { solutions to all the faults } \\
\text { detected. }\end{array}$ & $\begin{array}{l}\text { Having solutions to } \\
\text { all 60\% error }\end{array}$ & $\begin{array}{l}\text { Proffering solution } \\
\text { to all the 50\% error }\end{array}$ & $\begin{array}{l}\text { Proffering solution } \\
\text { to all the 45\% error }\end{array}$ & $\begin{array}{l}\text { Proffering solution } \\
\text { to all }\end{array}$ \\
\hline
\end{tabular}

For the fourth week, specification format was taught by the lecturer. Students were not allowed to make any contribution. They were tested based on the lecture there after. The grading format for the test was as presented in Table 4.

Table 4 Assessment criteria and scoring rubrics for week 4

\begin{tabular}{|l|l|l|l|l|l|}
\hline Specification Format & Excellent (A) & Very Good (B) & Fair (C) & Poor (D) & Fail (F) \\
\hline $\begin{array}{l}\text { 1.State the basic types of } \\
\text { specification formats and explain } \\
\text { any four of them }\end{array}$ & $\begin{array}{l}\text { Stating six (6) } \\
\text { types and } \\
\text { explaining four } \\
\text { concisely }\end{array}$ & $\begin{array}{l}\text { Stating six (6) types } \\
\text { and explaining three } \\
\text { concisely }\end{array}$ & $\begin{array}{l}\text { Stating six (6) } \\
\text { types and } \\
\text { explaining two } \\
\text { concisely }\end{array}$ & $\begin{array}{l}\text { Stating six (6) } \\
\text { types and } \\
\text { explaining one } \\
\text { concisely }\end{array}$ & $\begin{array}{l}\text { Stating six (6) types and } \\
\text { not explaining any }\end{array}$ \\
\hline $\begin{array}{l}\text { 2.Explain the CSI format and } \\
\text { state the three forms }\end{array}$ & $\begin{array}{l}\text { Concise } \\
\text { explanation of the } \\
\text { CSI format and its } \\
\text { three forms }\end{array}$ & $\begin{array}{l}\text { Concise explanation of } \\
\text { the CSI format and two } \\
\text { forms }\end{array}$ & $\begin{array}{l}\text { A brief } \\
\text { explanation and } \\
\text { explanation of one } \\
\text { of the forms }\end{array}$ & $\begin{array}{l}\text { A brief } \\
\text { explanation of the } \\
\text { CSI format and } \\
\text { inability to state } \\
\text { and explain any of } \\
\text { the forms }\end{array}$ & $\begin{array}{l}\text { Inability to explain the } \\
\text { CSI format and its forms }\end{array}$ \\
\hline $\begin{array}{l}\text { 3. Which of the forms would you } \\
\text { recommend for a two-bedroom } \\
\text { bungalow and why? }\end{array}$ & $\begin{array}{l}\text { Stating the } \\
\text { appropriate form } \\
\text { and substantiating } \\
\text { it with four good } \\
\text { reasons }\end{array}$ & $\begin{array}{l}\text { Stating the appropriate } \\
\text { form and } \\
\text { substantiating it with } \\
\text { three good reasons }\end{array}$ & $\begin{array}{l}\text { Stating the } \\
\text { appropriate form } \\
\text { and substantiating } \\
\text { it with two good } \\
\text { reasons }\end{array}$ & $\begin{array}{l}\text { Stating the } \\
\text { and substantiating } \\
\text { it with one good } \\
\text { reason }\end{array}$ & $\begin{array}{l}\text { Stating the wrong form } \\
\text { without reasons. }\end{array}$ \\
\hline
\end{tabular}

\subsubsection{Module 2:}

The second module also consisted of four weeks of lecture which included 1) lectures on Construction Specification Institute (CSI) specification format where the tutor presided over the class.

Table 5 Assessment criteria and grading rubrics for weeks 5, 6, 7 and 8

\begin{tabular}{|c|c|c|c|c|c|}
\hline $\begin{array}{l}\text { Specification } \\
\text { Format }\end{array}$ & Excellent (A) & Very Good (B) & Fair $(C)$ & Poor (D) & Fail $(\mathbf{F})$ \\
\hline 1.General section & Eight (8) items relating to work & $\begin{array}{l}\text { Six (6) items relating to } \\
\text { work }\end{array}$ & $\begin{array}{l}\text { Four (4) items } \\
\text { relating to work }\end{array}$ & $\begin{array}{l}\text { Two (2) items } \\
\text { relating to work }\end{array}$ & $\begin{array}{l}\text { Inability to mention } \\
\text { any of the relevant } \\
\text { preliminary items }\end{array}$ \\
\hline 2.Products & $\begin{array}{l}\text { Identification of the most } \\
\text { appropriate finishes under three } \\
\text { groups i.e. wall, floor and ceiling } \\
\text { finishes }\end{array}$ & $\begin{array}{l}\text { Identification of the most } \\
\text { appropriate finishes under } \\
\text { two groups }\end{array}$ & $\begin{array}{l}\text { Identification of } \\
\text { the most } \\
\text { appropriate } \\
\text { finishes under } \\
\text { one group }\end{array}$ & $\begin{array}{l}\text { Arbitrary } \\
\text { identification } \\
\text { based on intuition }\end{array}$ & Vague identification \\
\hline 3. Execution & workable installation methods & $\begin{array}{l}\text { Workable installation with } \\
\text { little lapses which are } \\
\text { negligible }\end{array}$ & $\begin{array}{l}\text { Fairly workable } \\
\text { installation } \\
\text { methods }\end{array}$ & $\begin{array}{l}\text { Poor installation } \\
\text { method that could } \\
\text { call for frequent } \\
\text { maintenance }\end{array}$ & $\begin{array}{l}\text { Installation method } \\
\text { is not workable at } \\
\text { all. It calls for } \\
\text { immediate } \\
\text { installation }\end{array}$ \\
\hline $\begin{array}{l}\text { 4. Principles of } \\
\text { specification }\end{array}$ & Stating up to seven (7) principles & $\begin{array}{l}\text { Stating up to five (5) } \\
\text { principles }\end{array}$ & $\begin{array}{l}\text { Stating up to } \\
\text { three (3) } \\
\text { principles }\end{array}$ & $\begin{array}{l}\text { Stating up to two } \\
\text { (2) principles }\end{array}$ & $\begin{array}{lll}\begin{array}{l}\text { Stating } \\
\text { principle }\end{array} & \text { one }\end{array}$ \\
\hline $\begin{array}{l}\text { 5. Method of } \\
\text { writing }\end{array}$ & $\begin{array}{l}\text { Combination of descriptive, } \\
\text { reference and performance. } \\
\text { Students should be familiar with } \\
\text { the referenced standard }\end{array}$ & $\begin{array}{l}\text { Descriptive and performance } \\
\text { approaches. Students should } \\
\text { be able to justify the need for } \\
\text { the performance style }\end{array}$ & $\begin{array}{l}\text { Descriptive } \\
\text { approach only }\end{array}$ & $\begin{array}{l}\text { Reference and } \\
\text { descriptive. Here, } \\
\text { reference } \\
\text { supersedes } \\
\text { descriptive and } \\
\text { students are not } \\
\text { familiar with the } \\
\text { referenced } \\
\text { standards }\end{array}$ & $\begin{array}{lr}\text { Reference } & \text { only } \\
\text { (students are } & \text { not } \\
\text { familiar } & \text { with } \\
\text { standards) } & \end{array}$ \\
\hline
\end{tabular}


However, samples of various divisions of the CSI formats were retrieved by the teacher from the internet and brought to class to guide the students in writing their own after the class. They were later asked to write on 'Finishes' of a proposed child care centre. The grading rubric was as presented in Table 5.

The 7th and 8th weeks consisted of two steps. They were lecture and written exercise on NBS specification format. This stage was conducted for four hours. The lecture on NBS was conducted by the instructor for two (2) hours. During the lecture, the description of NBS format, its levels and section format were explained. In this step, all the expected information that would guide the students in writing an effective specification was acquired.

The following week was to test students' understanding of what the teacher taught in the previous class. In this stage, the students were given the floor plan and elevations of a proposed child-care centre and asked to write specification of Ceramics and Concrete sections. At the end of the class, the students' works were collected and assessed for the performance outcomes of this stage. The assessment rubric is the same as the one used for weeks 5 and 6 (Table 6).

\subsubsection{Module 3:}

After the two modules described above, it was assumed that students had learned all they required to write a good specification. In this last stage, they were asked to write specification on their studio project for the semester. They were to pick four (4) clauses that were most important to their projects. During the class session for that day, each of the students was to identify the clauses that were important in his studio project.

Table 6 Scoring rubrics for module 3-weeks 9 and 10

\begin{tabular}{|l|l|l|l|l|l|}
\hline $\begin{array}{l}\text { Specification for studio } \\
\text { project }\end{array}$ & Excellent (A) & Very Good (B) & Average (C) & Poor (D) & Very Poor (F) \\
\hline Originality & Not copied & Copied part & Moderate copying & $\begin{array}{l}\text { Copied } \\
\text { greatly(suspicious } \\
\text { plagiarism) }\end{array}$ & Rolled specification \\
\hline $\begin{array}{l}\text { Appropriateness of } \\
\text { clauses }\end{array}$ & Specific to project & Missed one clause & Missed two clauses & $\begin{array}{l}\text { Only one relevant } \\
\text { clause }\end{array}$ & No relevant clause \\
\hline Drawings & $\begin{array}{l}\text { Complimenting } \\
\text { specification }\end{array}$ & $\begin{array}{l}\text { Little discrepancies } \\
\text { with specification }\end{array}$ & $\begin{array}{l}\text { High discrepancies } \\
\text { with specification }\end{array}$ & $\begin{array}{l}\text { Little relationship with } \\
\text { specification }\end{array}$ & $\begin{array}{l}\text { No relationship with } \\
\text { specification }\end{array}$ \\
\hline $\begin{array}{l}\text { Knowledge of current } \\
\text { building materials }\end{array}$ & Excellent knowledge & Very good knowledge & $\begin{array}{l}\text { Fairly good } \\
\text { knowledge }\end{array}$ & Little knowledge & No knowledge \\
\hline $\begin{array}{l}\text { Adherence to } \\
\text { specification principles }\end{array}$ & $\begin{array}{l}\text { up to seven (7) } \\
\text { principles }\end{array}$ & $\begin{array}{l}\text { up to five (5) } \\
\text { principles }\end{array}$ & $\begin{array}{l}\text { up to three (3) } \\
\text { principles }\end{array}$ & up to two (2) principles & one (1) principle \\
\hline $\begin{array}{l}\text { Approach } \\
\text { descriptive, reference } \\
\text { and performance. } \\
\text { Students should be } \\
\text { familiar with the } \\
\text { referenced standard } \\
\text { performance } \\
\text { approaches. Students } \\
\text { should be able to } \\
\text { justify the need for } \\
\text { the performance style }\end{array}$ & $\begin{array}{l}\text { only } \\
\text { onlive approach } \\
\text { not } \\
\text { with }\end{array}$ & $\begin{array}{l}\text { Reference and } \\
\text { descriptive. Here, } \\
\text { reference supersedes } \\
\text { descriptive and students } \\
\text { are not familiar with the } \\
\text { referenced standards }\end{array}$ & $\begin{array}{l}\text { familiar } \\
\text { standards) }\end{array}$ \\
\hline
\end{tabular}

\subsection{RESULTS AND DISCUSSION}

\subsection{Learning Styles of Participants}

During the group dynamics sessions, two (2) learning styles were identified in all which were later compressed into traditional and PBL. This is explained by an integrated model of teaching and learning styles based on students' and instructors' interaction developed by Grasha (2001). The result is shown in tables 7 and 8.

Table 7 Grasha-riechmann learning styles (Grasha, 1996)

\begin{tabular}{|l|l|l|l|}
\hline Competitive & \multicolumn{2}{|l|}{ compete with other students } & \\
\hline & share ideas and talents & Collaborative \\
\hline Dependent & need structure and support & \\
\hline & think for themselves, work alone & Independent \\
\hline Participant & eager to take part in class activities & $\begin{array}{l}\text { uninterested in or overwhelmed by what happens in } \\
\text { class }\end{array}$ & \begin{tabular}{c} 
Avoidant \\
\hline
\end{tabular} \\
\hline
\end{tabular}

Grasha (1996, 2002, and 2003) model identified six styles relating to the way that learners interact with each other. Statistics showed that only two of the styles-participant and avoidant - were related to each other. Thus, an individual could be both "collaborative" and "competitive," or both "dependent" and "independent," at the same time.

Based on Grasha model, the learning styles of specification writing by students was determined through observation during the group dynamics sessions. According to the observation, Grasha six learning styles were established. Out of 28 students, only one student (3.6\%) was competitive. Table 8 shows the statistics of learning style of students. 
Table 8 Learning styles of students

\begin{tabular}{|l|l|}
\hline Learning Styles & Frequency (\%) \\
\hline Competitive (1) & $1(3.6)$ \\
\hline Collaborative (2) & $8(28.6)$ \\
\hline Dependent (3) & $7(25.0)$ \\
\hline Independent (4) & $2(7.1)$ \\
\hline Participant (5) & $3(10.7)$ \\
\hline Avoidant (6) & $7(25.0)$ \\
\hline Total & $28(100.0)$ \\
\hline
\end{tabular}

The number of collaborative students was the highest (8) which accounted for $28.6 \%$ of the students. Very close to this are the dependents (25\%) and avoidants (25\%); next were the participants (10.7\%) and Independents $(7.1 \%)$. This shows that the most preferred learning styles were collaborative, dependent and avoidant, contrary to Grasha (1996) summation that an individual could be both "collaborative" and "competitive," or both "dependent" and "independent," at the same time, five of the students combined two of the learning styles. AJM, BNK, NTU and OMG were both collaborative and participant. However, another student (ABG) had a combination of competitive and collaborative learning styles which was in tandem with Grasha's findings.

From table 9, there were two (2) merger in the group dynamics; collaborative and participants, and competitive and collaborative. When the association in these groups is maximized, the attributes can enhance learning and make teaching effective. For instance, in the formal group, participants can be made to collaborate by sharing ideas and talents optimization (operant learning conditioning). In the same condition, the teacher could apply the facilitator approach by organizing a healthy competition in form of esquisse (quick approach or day project) which could be set within the group in a manner that can assist to bring out the required abilities and skills for specification writing.

\subsection{The Description of Group Dynamics, Learning and Teaching Styles}

Table 9 shows the summary of Modular Dynamics of Teaching, Learning and Assessment Profile in the selected institution. The pattern of this study adopted its "modus operandi" from Grasha (1996) teaching styles classification; for it juxtaposed the relevant teachers' teaching styles with the appropriate learning styles of students. This was employed for specification writing course; an integral part of architectural design studio. Two major teaching styles (traditional-didactic and revolutionary PBL) were experimented. The Grasha's Expert, formal authority and personal model teaching styles were grouped as the traditional method, while facilitator and delegator were categorized as the PBL style. For each of the three modules of lecture, both methods were adopted but in varying degrees.

For the first module in week one, the teacher discharged first as delegator and second, as facilitator. The students were delegated autonomously to explore the contextual meaning of specification and to find out the possible outcome of neglect of specification in practice. The teacher attempted to test their previous knowledge of specification by asking questions, exploring options, and suggesting alternatives. And the Teacher discovered that in a group of nine (9) persons in Group 1, six (6) persons had no idea about specification while three (3) persons had misconceptions about it. Two (2) persons thought it was the same as the bill of quantities while one (1) person thought it was the same as the schedule of finishes.

In group 2, they all knew about specification before their M.Sc. II. Eight (8) of them heard about it in their architectural graphics class while in 200 level. One of them said he has heard about it when he was on National Youth Service Corps (NYSC). The group 3 members (10 students) had summation of their response as follows:

"We all had basic introduction to specification writing from an interior design class we had although we did not go into details. Prior to that, most of us had an idea on what specification writing was about but did not really know much about it. Some people had encounters with specification writing during the IT training but did not get involved with it personally".(Group3)

In the second week of module one, the tutor displayed the expertise style in specification by transmitting basic information on the various approaches to writing specification. As a reactional measure and expectation from the Teacher's style of teaching, the students later brainstormed on how they expected to be taught, and their preferences for learning specification writing as follows, they submitted that: Specification should be introduced early in architectural education

- $\quad$ Live examples should be given (on-going projects)

- $\quad$ Citing of practical situations (on-site construction drawing documents)

- Course coordinators should engage in specification writing with the students to enable them understand it better (one-on-one teaching like architectural design studio). 
Table 9 Summary of modular dynamics of teaching, learning and assessment profile

\begin{tabular}{|c|c|c|c|c|c|}
\hline $\begin{array}{l}\text { Modules } \\
\text { Module } 1\end{array}$ & Course Content & $\begin{array}{l}\text { Teaching } \\
\text { Styles }\end{array}$ & $\begin{array}{l}\text { Instructional Tools \& } \\
\text { Methods }\end{array}$ & $\begin{array}{l}\text { Learning } \\
\text { Styles }\end{array}$ & Performance Scores \\
\hline Week 1 & $\begin{array}{l}\text { 1. An introduction } \\
\text { of the course. } \\
\text { 2.The Importance/ } \\
\text { Uses of } \\
\text { Specification } \\
\text { Document } \\
\text { 3. The need for } \\
\text { specification }\end{array}$ & $\begin{array}{l}\text { Facilitator } \\
\text { and } \\
\text { Delegator }\end{array}$ & $\begin{array}{l}\text { Take-home } \\
\text { assignment }\end{array}$ & $\begin{array}{l}\text { Group } \\
\text { dynamics } \\
\text { (participant/ind } \\
\text { ependent) }\end{array}$ & $\begin{array}{l}0-4 \text { marks }(\mathrm{F})-0 \% \\
4.5-4.9 \text { marks (D)-0\% } \\
\text { 5.0-5.9 marks (C)- } 0 \% \\
\text { 6.0-6.9 marks (B) - } 4(14.3 \%) \\
\text { 7.0 marks and above (A) }-24(85.7 \%)\end{array}$ \\
\hline Week 2 & $\begin{array}{l}\text { 1. Approaches to } \\
\text { Specification. } \\
\text { 2. Limitations to } \\
\text { Specification }\end{array}$ & $\begin{array}{l}\text { Expert and } \\
\text { Facilitator }\end{array}$ & $\begin{array}{l}\text { Group dynamics and } \\
\text { debate }\end{array}$ & Dependent & $\begin{array}{l}\text { Seven groups were represented in the debate. Four } \\
(57 \%) \text { of the groups performed excellently while two } \\
(29 \%) \text { displayed fairly good performance and one } \\
(14 \%) \text { performed poorly. }\end{array}$ \\
\hline Week 3 & $\begin{array}{lr}\begin{array}{l}\text { Sources } \\
\text { materials }\end{array} & \text { of } \\
\text { Specification } & \\
\text { Criteria for } & \text { the } \\
\text { selection } & \text { of } \\
\text { materials } & \\
\begin{array}{l}\text { Influences } \\
\text { Specification }\end{array} & \\
\begin{array}{l}\text { Principles } \\
\text { Specification }\end{array} & \\
\end{array}$ & $\begin{array}{l}\text { Personal } \\
\text { Model, } \\
\text { Expert and } \\
\text { delegator }\end{array}$ & $\begin{array}{lr}\text { Simple toilet } & \text { finish } \\
\text { specification } & \text { and } \\
\text { checking } & \text { of } \\
\text { specification } & \text { for } \\
\text { adherence to principles }\end{array}$ & Independent & $\begin{array}{l}\text { Seven groups were represented in the assignment where } \\
\text { seven (7) different faulty specifications were given out. } \\
\text { Three (3) }(42.8 \%) \text { of the groups performed excellently } \\
\text { while another three }(42.8 \%) \text { displayed very good } \\
\text { performance and one }(14.4 \%) \text { performed fairly good. }\end{array}$ \\
\hline Week 4 & $\begin{array}{l}\text { Specification } \\
\text { Format }\end{array}$ & Expert & Test & Dependent & $\begin{array}{l}\text { F-4 (14.2\%); D-0 (0\%); C-6 (21.6\%); B-4 (14.2\%); A- } \\
14(50 \%)\end{array}$ \\
\hline \multicolumn{6}{|l|}{ Module 2} \\
\hline Week 5 & $\begin{array}{l}\text { Specification } \\
\text { Format (CSI) }\end{array}$ & $\begin{array}{l}\text { Expert, } \\
\text { Formal } \\
\text { Authority } \\
\text { and } \\
\text { Delegator }\end{array}$ & $\begin{array}{l}\text { Lecture on how to write } \\
\text { "finishes" specification } \\
\text { using CSI Format }\end{array}$ & Dependent & Assessed in week 8 \\
\hline Week 6 & $\begin{array}{l}\text { Specification } \\
\text { Format (CSI) }\end{array}$ & Delegator & $\begin{array}{l}\text { Writing "finishes" } \\
\text { specification using CSI } \\
\text { Format }\end{array}$ & Dependent & Assessed in week 8 \\
\hline Week 7 & $\begin{array}{l}\text { Specification } \\
\text { Format (NBS) }\end{array}$ & $\begin{array}{l}\text { Expert and } \\
\text { Formal } \\
\text { Authority }\end{array}$ & $\begin{array}{l}\text { Lecture on how to write } \\
\text { "Ceramics" and } \\
\text { "Concrete" } \\
\text { specifications using } \\
\text { NBS Format } \\
\end{array}$ & Independent & Assessed in week 8 \\
\hline Week 8 & $\begin{array}{l}\text { Specification } \\
\text { Format (NBS) }\end{array}$ & Delegator & $\begin{array}{l}\text { Writing "Concrete" and } \\
\text { "Ceramics" } \\
\text { specification using NBS } \\
\text { Format }\end{array}$ & Independent & $65 \%$ (5 groups); $70 \%$ (1 group); and 80\% (1 group) \\
\hline \multicolumn{6}{|l|}{ Module 3} \\
\hline Week 9 & $\begin{array}{l}\text { Sample } \\
\text { Specification }\end{array}$ & $\begin{array}{l}\text { Facilitator } \\
\text { and } \\
\text { Delegator }\end{array}$ & $\begin{array}{l}\text { Writing specification } \\
\text { for two clauses in } \\
\text { students'studio work }\end{array}$ & $\begin{array}{l}\text { Independent/De } \\
\text { pendent }\end{array}$ & Assessed in week 10 \\
\hline Week 10 & $\begin{array}{l}\text { Sample } \\
\text { Specification }\end{array}$ & $\begin{array}{l}\text { Facilitator } \\
\text { and } \\
\text { Delegator }\end{array}$ & $\begin{array}{l}\text { Writing specification } \\
\text { for two clauses in } \\
\text { students' studio work }\end{array}$ & $\begin{array}{l}\text { Independent/De } \\
\text { pendent }\end{array}$ & $\begin{array}{l}\mathrm{A}=1(3.5 \%) ; \quad \mathrm{B}=24(85.7 \%) ; \\
\mathrm{F}=3(10.8 \%)\end{array}$ \\
\hline
\end{tabular}

As a result of the above reactions from the respondents, in week 3 and week 4, the tutor navigated her pedagogic compass by turning into illustration and direct example; she also transmitted (Expert style) the necessary information via the hand out documents, textbook and internet references that would enable the students to identify and learn the nitty-gritty of required instructional tenets and ingredients of the kind of specifications demanded for best practices. Their knowledge of building materials was also tested when they were being given the sources of information for material selection.

In a staccato manner, the second module was a balance blending of the traditional-didactic and the revolutionary PBL styles. During the fifth and sixth weeks, expert, formal authority and delegator teaching styles were dynamically engaged. Students were taught the art of writing specification using the CSI format. Live documents (as preferred earlier by the respondents) that connoted this format were used as a guide for the students to write for a 3-bedroom bungalow "finishes" and "opening" divisions. Similar styles were employed during weeks 7 and 8.

Module 3 (weeks 9 and 10) was based solely on the PBL style signifying that the tutor was a facilitator as well as a delegator. Here, she allowed the students to put to test all they have learnt about specification writing. 


\subsection{Pedagogic Recommendation and Benefits}

The experiential factorials and benefits of this study were very deep, insightful and challenging; the synergy and discoveries of blending the traditional-didactic and revolutionary Problem Based Learning Styles (hybrid) were thoughtful both to the respondent Teacher and the Learners. The characteristic identity of this hybrid formula yielded the following parametric measures:

- a one-to-one direct touch with the individual learners(Grasha (1996, 2002, and 2003);

- one step leads to a better one (systematic);

- deliberate focus on the learners' needs(relevant diets);

- flexible manoeuvring of Teacher's style in terms of alternative way of facilitating the class group dynamics;

- renegotiation of professional ethics and identity (Hokka and Etelapelto, 2014)

- pragmatic approach based on urgent and emergent needs;

- Real life situation rather than imaginary and abstraction approaches;

- Sustainable bridge-framework between the traditional past and revolutionary new revelations;

- Hands-on-experiences

- Immediate optimization of learners' preferences (as ingredients for teacher to work with) by the Teacher within the modular experimental set up e.t.c.

- A knowledge nexus strategy between design, precision and construction implementation

\subsection{CONCLUSION}

This study concludes that the state-of -the art in architectural pedagogy need not to divorce from its past; dovetailing the useful tenets of traditional mode of instruction into the revolutionary methods would retrieve the geniuses of the past for a learner to learn better. In this mode, Teachers would be able to teach with higher effectiveness, competency and professional proficiency. It emphasized constant selfevaluation, peer review, quality monitoring and assessment of the pedagogic qualities of the students' assignments (avoidance of plagiarism), standard performance tests and documentations in brainstorming-interactive class sessions. Results in the assessment rubrics attested that towards the middle of the semester when problem based learning (PBL) method was creatively blended with the tenets of didactic teachings, and then the performance scores of students were gradually on the increase; while interest of respondents grew rapidly in participatory project-based activities. Advance studies need to be done on both the GAP and SWOT analysis of pedagogic tenets in school on one hand and the professional demands in the field of practice. More so, more pathways still need to be paved in terms of the best practices applicable to the digital natives of the revolutionary age.

\section{References}

Aderonmu, P. A. (2012). A Framework for Sustainable Education in Nigeria: Strategies of Reintegrating Vocational Skills into Educational Curriculum. Architects Registration Council of Nigeria. 2012 Architects Colloquium, 2-22, Talos Press Nigeria.

Ali, A. S. (2009). Cost Decision making in Building Maintenance Practice in Malaysia. Journal of Facilities Management, 7, $298-306$.

Ali, A. S., Kamaruzzaman, S. N., Sulaiman, R., \& Peng, Y. C. (2010). Factors affecting housing maintenance cost in Malaysia. Journal of Facilities Management, 8, 285-298

Aderonmu, P. A. (2013). The Design Studio In Selected Schools Of Architecture In Southwest Nigeria: A Study Of Pedagogy, Culture And Environment. Unpublished Ph.D thesis. Covenant University, Nigeria.

Adewale, B. A., Aderonmu, P. A., Fulani, O. A, Jegede, F.O, Adeboye, A. B., Izobo-Martins, O. (2014). Designing to meet Human Needs: Place of EnvironmentBehaviour Studies in Architectural Education. 3rd World Conference Proceedings 'On Design, Arts And Education' (DAE-2014) 02-03 May, 2014, Dubrovnik, Croatia.

Bucholtz and Monk (1984). 'Beyond Style'. The Journal of the Graduate School of Architecture and Planning, Columbia University in the City of New York, 5(1984), $7-8$.

Dewey, J. (1904). The Educational Situation. Chicago, IL: University Of Chicago Press.

Dewey, J. (1938). Experience And Education. New York: Macmillan.

Kearsley, G (1994-2008). Constructivist Theory (J. Bruner). Theory into Practice (TIP) database. [Online] Available: http://tip.psychology.org/knowles.html.

Grasha, A. F. (1996). Teaching with style: The Integration Of Teaching And Learning Styles In The Classroom. Retreieved November 26, 2004 from the University of Maryland Center For Teaching Excellence:website:http://www.cte.umd.edu/library/podresourcepackets/defining teaching/style.html.

Grasha, A. F. (2002). Teaching With Style: A Practical Guide To Enhancing Learning By Understanding Teaching \& Learning Styles. San Bernadina, CA: Alliance.

Grasha, A. F. (2003). The Dynamics Of One-On-One Teaching. The Social Studies, 94(4), 179-187.

Hokka P. and Etelapelto A. (2014). Seeking New Perspectives on the Development of Teacher Education: A Study of the Finnish Context. Journal of Teacher Education, 65(1), 39-52.

KJV, (2013). Genesis 6:15 (KJV). Noah's Ark; the Fashion of Noah's Ark. KJV022GL-50M-BSN-2013 (Bible Society of Nigera)

Learning Directory (2010). Learning Styles and Multiple Intelligences online: http://www.ldpride.net/learningstyles.MI.htm

Lam, P. T., Kumaraswamy, M., and Ng, S. T. (2001). The Multiple Roles of Specifications in Lean Construction. In Proceedings IGLC-9-Ninety Annual Conference of the International Group for Lean Construction.

Lincove, Osborne, Dillon, and Mills, (2014). The Politics and Statistics of Value-Added Modelling For Accountability of Teacher Preparation Programmes. Journal of Teacher Education, 65(1) 24-30.SAGE Publication, USA.

McFarland, A. E. (2010). An End User Approach to Teaching Specifications. International Journal of Construction Education and Research, 6(2), 83-103.

OALD (2010). Oxford Advanced Learner's Dictionary, Intl. Student Edition, 329 Oxford University Press, UK.

Olotuah, A.O. (2002). "Architecture and Cultural Sensibilities: The Implications for National Unity". Arts and Social Sciences Forum Journal, 45-56.

Olukanni, Aderonmu, Ogbiye, and Akinwunmi, (2014). Re-integrating Vocational Technical Skill Acquisition into the educational curriculum: capacity building for future Professionals. Proceedings of ICERI2014 Conference 17th-19th November 2014, Seville, Spain.

Pring, (2007). Continuum Library of Education Thought. Continuum International Publishing Group, NY.

UIA/UNESCO,(1996). Charter for Architectural Education. (June 1996). www.unesco.org/most/uiachart.htm

Yiu, C. Y. (2008). Intelligent Building Maintenance- A Novel Discipline. Journal of Building Appraisal, 3, 306-317. 